\title{
The Fiduciary Accountability of Directors Ensuring Sustainable Business Growth in Public Listed Companies and SMES
}

\author{
S. Lakshmi Gandhan, Daisy Mui Hung Kee
}

\begin{abstract}
Purpose of study: Several studies are made on innovation, marketing orientation, social media and decision made in the black-box. However, countries such as England, Singapore and quite recently Malaysia legislated company law for a proper governance of the company and laws passed now make directors are more accountable of their fiduciary functions toward the company. Such law legislated is due to numerous court cases tried on breach of fiduciary and there are circumstances where corporation were liquidated. To date there is an inadequate study on the fiduciary accountability of directors or the Board of Directors (BOD) towards innovation and sustainable business growth. Despite innovation and sustainable business growth, directors are accountable for their actions such as approving expenditure on innovation, which result in low profit. However, there are studies on the "black box" in which decisions are made and. The aforesaid study lacks in one particular area, that is, fiduciary accountability of directors, which go beyond the decision-making process and its implementation. Since Malaysia Parliament passed the Companies Act 2016, which comes into effect in 2017, fiduciary duty is included in the Act. This study will look into the innovation and sustainable business growth and how the fiduciary accountability of directors moots innovation technologically, encouraging innovative knowledge through social-media among the employees, product innovation to meet customers' needs and, of course, business sustainable growth.
\end{abstract}

Methodology: In order to have more reliability of the aforesaid a comparative study is made between one of public listed companies and SMEs.

Result: A final note, the present study on would trigger academic vigor in future because new concept of "fiduciary accountability" which is introduced in this literature.

Index Terms: Fiduciary Accountability, Innovation, Sustainable.

\section{INTRODUCTION}

In an era of the digital world, the fiduciary accountability of directors cannot be denied their role in ensuring the sustainable business growth. This, of course, could be achieved through innovating or reinventing new products in the market to capture the customers' choice. The dispute of trade imbalance at the world stage among the developed countries, US and China could possibly affect the developing countries. Having in mind of such political and economic issues, entrepreneurs or directors need to produce innovative products by using latest technological machines and cutting

Revised Manuscript Received on October 15, 2019.

S. Lakshmi Gandhan, School of Management Universiti Sains Malaysia, Pulau Piinang, Malaysia. gandhanpillai@gmail.com

Daisy Mui Hung Kee, School of Management Universiti Sains Malaysia, Pulau Piinang, Malaysia. dasy@gmail.com. the cost of production so that products sold at the market either locally or globally would be priced competitively low and with quality assurance. It is supported recently that new products were innovated to cater for customers and products sold internationally (Jacob \& Peters, 2015). If one reads the newspaper and Enron matter, one think strikes the mind is the lack of accountability of directors discharging fiduciary functions. Not surprisingly, corporation with good credential would be go into liquidation because of inability to settle the debts. When the court lifts the veil of the corporation, it is found, to some extent, directors have breached the fiduciary duties putting the corporation into financial crisis. Contrarily, directors have driven the company to another competitive level by innovating new products, branding and seeking new markets.Since there is lack of academy contribution in this particular subject any study on fiduciary accountability of direcors, predictor, contributing to sustainable business growth would trigger future study of the aforesaid academically. Notwithstanding the fiduciary encompasses in wide application in social, political and business, to date there is no correct definition and their application. Seeking to define fiduciary accountability is 'one of unfinished task of modern legal scholarship'(Harding, 2013), and the 'holy grail' of fiduciary jurisprudence that continue (Waters, 1986) to be a blot on our law' (Weinrib, 1975). The word 'fiduciary' is originated from the Latin so-called Fiduccia which means trust or confidence. The fiduciary accountability of directors is an area where not much is contributed academically. Most studies encompass on the area of entrepreneurial orientation, decision making of managers, market orientation and innovation but the specific area of fiduciary accountability is not explored. In the actual business scenario, fiduciary accountability of a director is predominately important in contributing to innovation which is essential to the sustainable growth. Undoubtedly, decision making is one of components in the fiduciary accountability but fiduciary accountability has a wider legal and business implications if it is breached. If fiduciary accountability is expounded it will give arise to spectrum of responsibilities such as the stakeholders, market orientation, branded orientation, management expenditure and innovation. Fiduciary accountability is more pronounced in the listed and transnational corporations but study on how directors owe fiduciary accountability in SMEs is not explored. 


\section{SMES}

Insofar law is concerned, fiduciary responsibility of directors not only covers listed company but also covers private or limited liability corporation (Companies Act 2016). This paper draws conclusions on how the fiduciary accountability in the listed company and SMEs have the sustainable growth by means of incrementally innovating the existing plant of production, products market strategy, patent rights and more importantly market perception. At this juncture, it is appropriate to give the definition of fiduciary accountability.The fiduciary accountability of directors is primarily to the company. In the legal context, corporation is the legal personality and it is during the annual general meeting directors acting as capacity has to declare the audited statement of account which reflects the success or failure of any venture. Lord Davey in the case of Salomon said that when a company is incorporated it becomes a juristic personality in which company and members are separated. The company not only a legal entity but also economic entity carrying out the business activities. Flannigan (2014) correctly asserted that 'today few axioms are better established that a corporation owns property in its own right and that shareholders as such have no interest in that property and the board are authorized to act one behalf of the corporations'. Along the same lines, fiduciary accountability of directors or a director is the trustee who remains accountable for the internal organization and externalities. Failure to provide cogent justification of their action would result serious implications to the BOD or a director. For this study fiduciary accountability is defined as a director's duties or BOD duties towards the company that company is piloted by them/him to accomplish the desired aspirations of the company ensuring positive returns, overseeing their downline performance, bringing futuristic ideas and all of which would contribute to the business growth and remain accountable for their actions to the company and stakeholders. Judge Major correctly concurred that core business is carried out by a group of person entrusted as trustee in assuring positive returns to the beneficiaries. (Major, 2009).In Malaysia the Industrial Production Index increased by $1.1 \%$ in the month of June 2018. Furthermore, a further growth is noted in the index of manufacturing at $4.5 \%$ and electricity index at $3.0 \%$ (e-Statistik, 2018). It is expected that the domestic demand to grow causing positive economic activities, promising income growth with a stable labour market (World Bank, 2018). Whilst the external environment looks imperative, there is the possibility for the export sector in Malaysia to increase progressively (World Bank, 2018).

\section{A. Research questions and objective}

The objective of the aforesaid is to find out whether directors are accountable for their fiduciary functions or duties toward the corporation which is reflected in the sustainable business growth. Secondly, to find out the causal link between the fiduciary accountability of director and innovation contributing to the sustainable business growth. As such three questions are posed in this study namely:

i. To what extent is the causal link between fiduciary accountability of directors and sustainable business growth. ii. How is marketing orientation and innovation contributes to sustainable business growth?

iii. How are directors accountable in fiduciary sense in ensuring innovation and market all of which contributes to sustainable business growth?

\section{B. Significance of the study}

The study is significant in the sense that it explores how the fiduciary duties of directors are accountable not only to the corporation but also other stakeholders. Since there is inadequate study on accountability of director's fiduciary function, any study on this specific study would go a long way academically.

\section{LITERATURE REVIEW}

It is noted that considerable government effort has been taken to expand growth of small and medium sized enterprises (hereinbefore referred as SMES) within the economy

(Curran., 1999). Undoubtedly, there are consensus of studies which revealed that innovation and marketing contribute to the sustainable growth of a corporation. However, the fiduciary accountability of directors plays a pivotal role in business growth and also determine to what extend innovation could be implemented in the corporation. In literature point of view, fiduciary accountability of a director or Board is not explored linking their perquisite contribution to innovation.

\section{A. SMES in Malaysia}

Currently, the growth of economic of both developed and developing countries are attributed to the activities of SMEs. Not only SMEs can churn the economic but also a source of employment, producing heterogeneous products and services for the customers' satisfaction. Some of these corporations are inclined towards innovating products as well as processing in which competencies are inescapable (Szczepanska-Woszcyna, 2014, 2016).In Malaysia the government plays a major role in providing business opportunities for SMEs to grow. Having in mind, the government has implemented attractive policies and initiatives for SMEs and entrepreneurial activity to grow. In order to simply the incorporation of a company, the government legislated the Companies Act 2016 to allow the entrepreneurs to incorporate a company with a single person. To meet the current international standards, the aforesaid Act overcomes the complication of registration which is expected to stimulate the growth of more such corporations in near future (SMEs Corporation, 2016).

Table depicts that service section has the largest share of $89.2 \%$, manufacturing registers about $5.3 \%, 4.3 \%$ construction, $1.1 \%$ of agriculture and $0.1 \%$ mining. TABLE1: NUMBER OF SMES BY SECTOR 2017

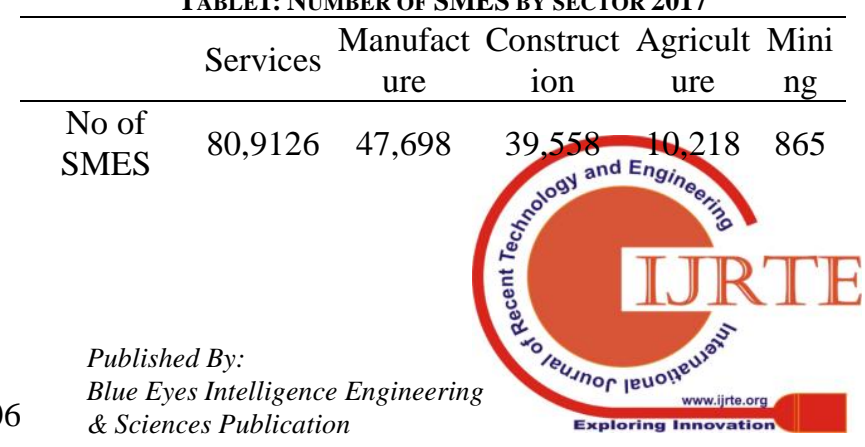


Sum $809126 \quad 47698 \quad 391558 \quad 10218 \quad 865$

Source: Department of Statistic of Malaysia 2017

TABLE2: CONTRIBUTION OF SMES TO OVERALL GDP BY ECONOMIC

$$
\text { Activity (\%) }
$$

\begin{tabular}{|c|c|c|c|c|c|c|c|}
\hline Yea & $\begin{array}{l}\text { Agric } \\
\text { ulture }\end{array}$ & $\begin{array}{c}\text { Mini } \\
\text { ng }\end{array}$ & $\begin{array}{l}\text { Manufa } \\
\text { cturing }\end{array}$ & $\begin{array}{l}\text { Serv } \\
\text { ices }\end{array}$ & $\begin{array}{l}\text { Constr } \\
\text { uction }\end{array}$ & $\begin{array}{l}\mathrm{Du} \\
\text { ties }\end{array}$ & GDP $\%$ \\
\hline 2010 & 4.3 & .0 & 7.7 & 19.6 & .9 & 0.2 & 32.20 \\
\hline 2011 & 4.3 & .0 & 7.4 & 19.9 & .9 & 0.3 & 32.80 \\
\hline 2012 & 4.1 & 0.1 & 7.4 & 20.1 & 1.0 & 0.3 & 33.00 \\
\hline 2013 & 4 & 0.1 & 7.5 & 20.5 & 1.1 & 0.3 & 33.50 \\
\hline 2014 & 4.5 & 0.9 & 7.8 & 21.1 & 2.0 & 0.4 & 35.90 \\
\hline 2015 & 4.3 & 0.2 & 7.9 & 21.4 & 2.1 & 0.5 & 36.30 \\
\hline 2016 & 4.1 & 0.2 & 7.9 & 21.8 & 2.1 & 0.5 & 36.60 \\
\hline
\end{tabular}

Source: Department of Statistics of Malaysia

Table 2 depicts there is a significant growth of SMEs, among the sectors which shows a distinctive growth at the service which is expected to grow in near future. In 2014 share of overall employment in Malaysia comes from the SMEs which is the driving tool to increase the gross domestic product. Financial institutions and government funding are the facilities available for the corporations to finance business operation. However, it seems a difficult task for the prospective entrepreneurs of SMEs to access the loan facility from the financial institutions because they do not have collateral security (Harun, Said, Subramaniam, \& Ismail, 2013).

TABLE3: TOTAL SME GROWTH IN EMPLOYMENT, EXPORTS AND PRODUCTIVITY

\begin{tabular}{lllll}
\hline Year & 2010 & 2011 & 2012 & 2014 \\
\hline Share of SME employment & 57 &. & 16 & 65 \\
SME employment growth & 57 & 3.9 & 17 & 21.6 \\
Share of SME export & 57 & 5.9 & 16 & 17.8 \\
$\begin{array}{l}\text { Export productivity (RM) } \\
\text { SME productivity (RM) }\end{array}$ & 58 & 6.3 & 18 & 6.2 \\
$\begin{array}{l}\text { SME productivity } \\
\text { growth }\end{array}$ & - & 3.2 & 0.2 & -6 \\
Source: Department of Statistics Malaysia & & & \\
\hline
\end{tabular}

Table 3 depicts the growth of SMEs between 2010 and 2014 in terms of employment or export. The export for the year 2013 and 2014 remains same whereas the employment contributes about $65 \%$ of total employment sector in Malaysia. However, the productivity decreased in 2014. Studies indicated that failure rates are rather high among new entrants because they have inadequate knowledge of business, inability to manage the workforce and more importantly the entrepreneurial zeal is lacking (Harun et al., 2013; Hironaka, Ashhari., \& Zairyawati., 2017). In the long run, such corporations could not sustain because they do not have the capability to capitalize on future market prospects (Hofer \& Charan, 1984). Sany Sanuri, Rushami, and Azanin (2014) observed that market orientation is one of the important variables for the firm performance and success. This is due to the corporation is in position to find out the customers need and create new products.

\section{B. Listed corporation}

Security Commission Malaysia has drawn the regulatory benchmark for a company which is suitable for a Main Market listing or an ACE Market listing. For a company to be listed must meet the requirement of uninterrupted profit of three or five years on audited financial statement with profit after tax reduction of RM 20 million. In 2017 total number of companies is 905 and increased by two 2 for the month of March 2018.

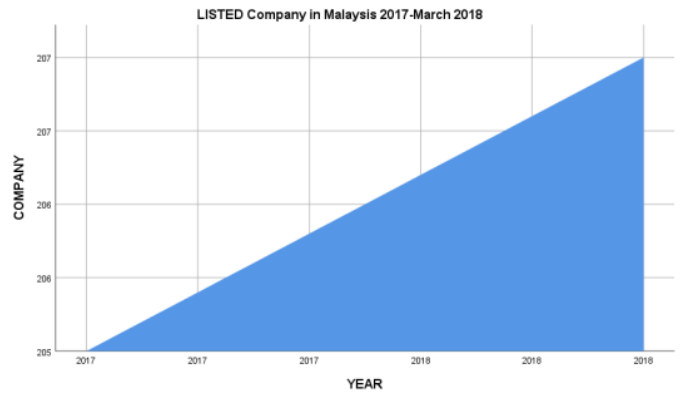

Fig 1: Listed Corporation of Malaysia between 2017 and 2018

\section{Innovation capability}

Innovation capability is said to be synonymous with dynamic capability. Hii and Neely (2000) assert that innovation capability is about generating innovative ideas, seeking new or create new markets and transforming the available resources into productive use. For a corporation (refers to a firm or organization) to occupy a competitive edge, it is necessary to generate knowledge among the workforce and it is that knowledge contributes to electrifying change in the organization (Drucker, 1986). Also, innovation capability as the combination of knowledge and technology deployed in producing products, services, processes and systems (Kogut \& Zander, 1992; Minna, 2016). Moreover, the capabilities of innovating could be dispersed in different sections in the organization ensuring strategy of innovative performance which would contribute to the sustainable business growth. The effective way for the corporation to sustain business is to focus more on market innovation (Jaworski \& Kohli, 1993). Owing to responsiveness to market sentiments corporation is able to harness profit and remain competitive(Han et al., 1988). This is only feasible if the corporation is inclined to the market-orientation, and willing to innovate their products for the customers' needs (Narver \& Slater, 1990). The success of the corporation hinges onto the ability to innovate their products, technological change and allowing knowledge and new ideas into new products, processes and system benefiting the corporation, shareholders and customers. Moreover, research on innovation is wide spectrum ranging from projects or organizations, individual (Drucker, 1986), or by "the intensity of innovation"(Hollenstein, 1996). 
Table4: Innovation definition

\begin{tabular}{c}
\hline Author \\
\hline Joseph \\
Schumpeter \\
$(1930)$
\end{tabular}

Peter Drucker (1954)

Howard and

Sheth (1969)

Mohr (1969)

Demeanour and

Evan (1984

Kenneth

Simmonds (1986)

Damanpour (1991)

Davenport

(1991)

Evans (1991

Covin Slevin

(1991),

Lumpkin and

Dess (1996),

Knox (2002

Henderson and

Lentz (1995

Rogers (1998)

Cohe, Malin, and Sahpurwala (2013)

Anneke,

Natalie, and

Ramón

Gil-García

(Shengyen,

Ursula, \&

KattnerCarelyn, 2017)

Innovation is defined in various ways by the researchers and Board of Directors, as for instance, it is more prevalent in an organization of what activities to be carried out within the given scope of production, and those which can be outsourced. Precisely, innovation has different perspectives such as radical, incremental changes in products, processes, market, business model and lately ideas which is integrated in the corporation. The purpose of innovation is to ensure the corporation generates profit to the shareholders and gives confidence to other stakeholders. Table 4 shows different definition of innovation given by the authors. Some innovation used is more of the effects of innovation instead of attributes as for example innovation is described as "revolutionary", "disruptive", "irregular" or "discovery" (Freeman, 1994; Garcia, Rosanna, Calantone, \& Roger., 2002; Tushman, Michael, O’Reilly, \& A., 1977). Although innovation on technological contributes to fast production, learning philosophy within the organization determines which department needs to be restructured in order to alleviate the rising cost of expenditure. In certain circumstances, corporations strategize on the performance using the resources for development, acquiring other companies, R \& D and branding its products (Han et al., 1988; Laine, 2012). Schumpeter explained that innovativeness enhances profit in which a company is able to use new resources with combination of entrepreneurial input (Schumpeter, 2011) and innovating technologically, creating new market and restructuring the organization to meet the current need (Ljiljana Božic \& Ozretic-Došen., 2015) all of which ensures sustainable business growth. Additionally, Damanpour, Fariborz, Gopalakrishnan, and Shanth (2001) argued that organizational performance is a function of innovating, not adopting radical, technical, product, or any one type of innovation alone'. Baker and Sinkula, Baker, William, Sinkula, and James (2002) are skeptical about incremental innovation on the basis of inability to sustain the corporation in the long run which eventually lose out to the other competitors. This is rebutted by Palmer, Roger, Brookes, and Richard (2002) because incremental innovation has the tendency to innovate at the stages level. While incremental innovative is rather less disruptive, as matter of time there is a tendency for innovation breakthrough. In essence, the multi-national or transnational corporation sustains their growth by releasing new version products and incrementally improving their products to meet the competitive market (Mitsuru Kodama \& Shibata, 2015). Consequently, radical and breakthrough innovation caused pendulum shift of latest technologies and seeking new markets, the transformation of existing market, selling their products across the border with reduced price and meeting international standard (Leifer et al., 2000; O'Connor, 2006). To achieve this end, it is necessary for the corporation to have distinct the knowledge and willingness to allocate some fund to purchase new machines. At the surface allocating high resources to have new products is challenging and risky, if the outcome of investment is not nurturing positive impact to the corporation there is the possibility of going into bankruptcy.Moreover, Maxwell and Ernest (2009)asserted the incremental innovation is primarily important to extend the product life cycle until radical innovation is needed to create new products for the customers at large. The failure of innovation is due to the lack of market-consumer expectations and poor evaluation of products by the consumers. Meanwhile, researches have verified that new features added into the products consumers evaluated highly but when new features are added to the high-sophisticated product it does not impress the consumers (Goa \& Cui, 2016; Mukherjee \& Hoyer, 2001; Pappenheim, 2016). Insofar innovation in marketing is concerned, Rogers identified five factors which determine the diffusion of innovations commonly being superior product performance, meets the customer's perception. Market innovation is now prevalent because the corporation identifies the opportunities for a change which induces directors to innovate their products

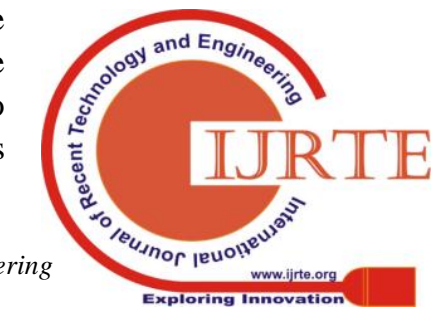


(Simmonds, 1986). At this juncture, innovation enhances opportunity for a corporation to provide quality product to meet the customer satisfaction. Having identified the lucrative market, research is embarked by the corporation to ascertain what type of products to be marketed. Simmonds (1986) distinguished eight paradigm of marketing, that is, market, system, customer satisfaction, choice, exchange, conflict and influence. It is the customers who determine whether the innovated product becomes compatible with them (Mukherjee \& Hoyer, 2001; Pappenheim, 2016; Sandberg, 2008).

\section{Fiduciary accountability}

Fiduciary accountability is introduced in this literature, and hopes it would widen its scope in the academic study. It has to be noted that director duties are fiduciary in nature and their relationship with the company is based on trust, hope and expect, that is, similar to the relationship between a trustee and beneficiary. Joseph Warburton (2011) explains that fiduciary duties 'provide a set of standards that law applies to restrain insiders from exercising their discretionary power in contingencies not specifically foreseeable and over which the parties could not contract. Insofar corporate law is concerned, it is correct to say that director stands in terms of fiduciary relation to the company and powers emanating from the constitution or statutory law has to be exercised in the fiduciary capacity (Bee Chan, Koh, \& Ling., 2006). The fiduciary relationship between a director and the company gives the director a venerable position to abuse. Judge Mason in the case of Hospital Products Ltd v United States of Surgical Corporation (1984)156CLR,103 remarked that 'the fiduciary relation may be expressed by saying that he is under an obligation not to promote his personal interest by making or pursing a gain in circumstance in which there is a conflict ore substantial possibility of a conflict between his interests and those of the persons whom his is bound to protect'.In case a director who had carried out his fiduciary duties correctly but his business strategy after which was a failure he would be held accountable to the stakeholders (Glover v Willeet \& Others, 1996). The importance of law in the societal and institutional influence on the corporation cannot be taken lightly because company law provides 'a set of coercive formal requirements with specific incentives and penalties (Oliver, 1991). This is further elaborated as 'a broad cultural framework that influences organizations both mimetically and normatively (Edelman \& Suchman, 1997). In Malaysia the fiduciary accountability is formulated in the Companies Act 2016 hereinbefore is referred to as (C.L 2016), section 213 provides that a director shall at all times exercise his power in good faith in the best interests of the company whereas subsection of aforesaid section wants the director to exercise reasonable care, skill and diligence.Apart from accountability to the stakeholders, presuming the Board of Directors has miscalculated the strategy or gained personally out of the corporate assets he would be imprisoned if he is convicted (Companies Act 2016). According to Lord Russel in the case of Regal Hasting stated that 'who by the sue of fiduciary position make a profit, being liable, to account for that profit, in no way depends on fraud, or absence of bona fides or upon such questions of consideration as whether the profit would or

should otherwise have gone to the profiteer'. Accountability arises when an individual has to justify his decision made to another person (Schlenker, 1980; Tetlock, 1983; Tetlock, Skitka, \& Boettger, 1989) which is analogous to accounting studies. It normally applies to person whose decision resulted in serious repercussion in which that person has to give a satisfactory justification, failing which he would be legally prosecuted (Stenning, 2000). To make one accountable it creates a different behavior portraying the acceptability of heuristic and 'defensive bolstering'(Tetlock, 1983; Tetlock et al., 1989). Moreover, the acceptability of heuristic affirms that the accountability influences the concerned person to seek for an alternative solution to mitigate (Tetlock., 1985). The recent study of accountability of directors argued the accountability is a continuous process and composes of four stages (Keay, 2015). These include the decision made for the business is proper and a legal duty to disclose everything to the shareholders; the second stage is justification for their actions or whatever omissions and risks; evaluation of their outcome falls during the third stage; and finally if their business judgement nurtured profit or losses, but not compulsorily, possibly to shoulder the outcome of their actions (Keay, 2017). In the public service, officers while discharging their duties remain accountable for their wrong actions unless they can establish otherwise. Likewise, in private sectors, directors are held accountable for poor return on investments. This aligns with agency theory in which the agents have to account for their actions to the principals. It is supported by neo-classical economics and law scholars which give, inter alia, that the shareholders are the owner of the corporation and could be correctly said as some of them are elected principals to carry out the functions as the agent of the corporation: (Pilon 1982). Agents like any other profit seekers would seek to enrich themselves and 'opportunistic actors given to self-interest seeking with guile'(Williamson, 1966). Such sentiments are prevalent in the corporate governance and therefore accountability is necessitated for a director to accomplish the company's strategy. Their real position is that they occupy fiduciary relationship with the company.

The Board of Directors is given the power by the shareholders so that they can manage the management and business affairs of the corporation. With such power given to them the Board is in position to manage the capital, reduce the capital, buy-back shares and declare dividends to the shareholders. Such function is found in the listed corporations but it is not sure for SMEs. Section 211(2) of Companies Act 2016 provides that 'the powers are necessary for managing and for directing and supervising the management of the business and affairs of the company' and section 213(1) also gives power to a director to exercise his powers for a proper purpose and good faith'. This is the statutory power given to a director to run the business with good faith and best interests of the corporation. The aforesaid section applies generally for all corporation irrespective of a listed company. 
In sum, the company law in Malaysia explicitly pronounces effective mechanisms in different stages of accomplishing fiduciary accountability of directors such as accountability to the shareholders, creditors, customers, external supplier and employee. If a company borrows money for business venture, the fiduciary accountability of directors shifts to the creditors. This is because of the inability to service debts the creditors would cause catastrophic disaster to the company such as appointing receiver or petitioning to wind-up the corporation. Last but not the least, fiduciary accountability is applied as an independent variable in this study to determine innovation is carried out in order to contribute to the business sustainable growth. In reality, the shareholders do not absolutely trust the directors and the degree of trust varies. Owing to this, the Board needs to achieve credibility and reputation as they are given the licence to manage the company properly (Schillemans \& Basuioc, 2015). Fiduciary accountability not only makes the board or a director accountable for their/his action but also promote the awareness of future market where their decisive role is primarily important in benefiting the corporation (Keay, 2017; Schillemans \& Basuioc, 2015).

\section{E. Market Orientation}

With quick reaction of customers currently due social media, corporations have to keep track what is really happening in the market and hyperactively indulge in analysis, customers' preferences, segmentation, gather information, and a radical change of product all of which are known as market orientation. Overseeing current market and foreseeing the future markets will change the mindset of the customers; a short span of time new products are spiraling in the market; and radical change of products posit a company in strategy position in the industry (Kolter, 2017; Kotler, 1993). Bearing in mind of branded products in the market, a company which is market-oriented performs well in terms of sale with the assurance of positive returns to the corporation (Narver \& Slater, 1990). It is the concerted effort of all players in the organization which contributes sustainable business growth (Jaworski \& Kohli, 1993). This is due to the team efforts in ensuring quality products and services to customers.

\section{F. Sustainable business growth}

To date there is no proper definition of what is sustainable business growth. However, it is the sustainable growth which could be attributed to the financial performance, an increase in the sale of products, products have competitive advantage, caring customers and as well as employees, and maintaining. Moreover, it is defined as a new concept which covers the company has the capacity to learn, 'adapt, reinvent, create and reorient to maintain a lasting and distinctive position in the market by offering buyers above-average value today and in the future (consistent with the paradigm of innovative growth) through organic variation constituting business models, and arising from the creation of new opportunities, objectives and responses to them, while balancing the interests of different groups (Grudzewski, Hejduk, Sankowska, \& Wańtuchowicz, 2010)

\section{G. Theoretical Framework}

The theoretical framework is about the fiduciary accountability determines innovation, moderator, for sustainable business growth. No doubt the literature covers legal aspects of fiduciary accountability, the scope of fiduciary functions of directors also includes market orientation which includes customers' preferences. It is impossible to image without customer preferences how a company is going to harness profit (Narver., Slater, \& Tietje, 1998).

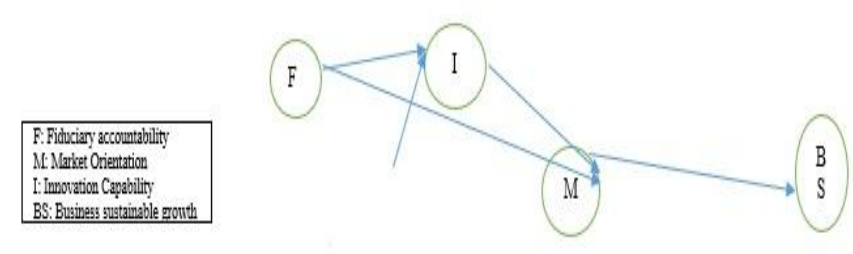

Fig 2: Theoretical Framework

\section{H. Hypothesis}

Based on the above the following hypotheses are as follow

H1: The fiduciary duty of a directors gives rise to innovation

$\mathrm{H} 2$ : Incremental innovation increases the production.

H3: The BOD or a director promotes and indulge in the company sustainable business growth

H4: Advertisement on social media increases the sale

\section{METHODOLOGY}

For purpose of this methodology is semi-structured interviews in which open-ended questions are preferred in order to find out the particular areas (Amirav \& Higginbottom, 2014; Mathers, Fox, \& Hunn, 2002). Although the open-ended question defines the area of research, it gives an opportunity both the interviewer and interviewer to explore the specific area of the study in detail and to clear any doubts arising (Amirav \& Higginbottom, 2014; Mathers et al., 2002).

The economical way of research and to find out causal link of variable is through telephone interviews. It is effective to communicate businessmen or directors to furnish the required details for the study (Lavakras, 1987; Mathers et al., 2002). However, the setback hinges onto lack of visual contact of expression and likely the respondent may not answer. To facilitate smooth transaction, covering letter was sent stating the expected length of interview.Obviously,telephone conversation upholds privacy without physical presence in comparison to face to face interview (Holt, 2010; Vogl, 2013). The setback of face to face interview hinges on to the psychological disturbances of interviewee which hinders free flow of discussion (Odoom, Dorson, \& Acheampong., 2017). Bearing in mind of getting bored or fatigue, interviews were conducted constructively with direct questions relevant to the theoretical framework of the aforesaid study (Amirav \& Higginbottom, 2014; Lavakras, 1987; Mathers et al., 2002). 
Whilst interviewing, questions posed to the respondents of managerial level were not long-winded but confined to relevant areas commonly being innovation, fiduciary accountability, market orientation and sustainable business growth. In certain situations, the interviews were deferred to some other days convenient to them. Since the focus of the study is comparative between a listed and SMEs, similar questions were posed to the interviewees to maintain the reliability.

\section{A. Data Analysis}

Since the study confines to food production, one prominent listed corporations is studied to test the variables and the casual link as depicted the Figure 2.

\section{1) “AB" Listed Corporation}

The above mentioned corporation is a manufacturing of one of the essential commodities for consumers. With a humble beginning with the capital injection from Japan and local Malaysian, the company had managed to sustain its business despite the fact of stiff increase of the raw materials. In 2011 the aforesaid company was listed in Bursa Malaysia (stock exchange) and it was reputed one of fifty listed company in this country. Lately, the company was bought over with the existing infrastructure. To date there three main subsidiaries of listed corporation which largely contributes to its growth. Since its inception, the company extended in the Middle East to supply the commodity ensuring the product does not have any reversible effects on health after consumption. The Figure 3 depicts the workforce of the said corporation comprising of board of directors, executive directors and others.

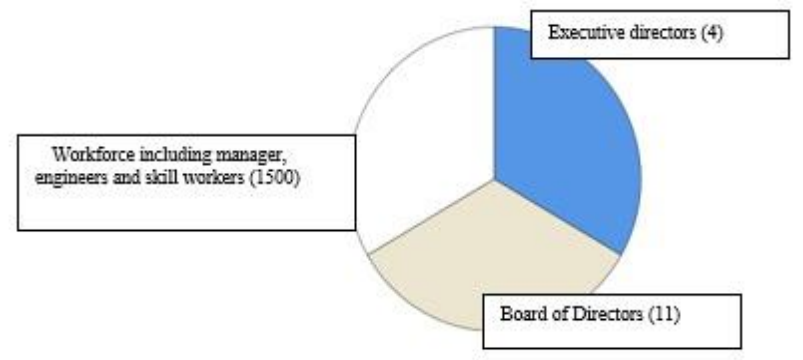

Fig 3: Total Human work force of corporation

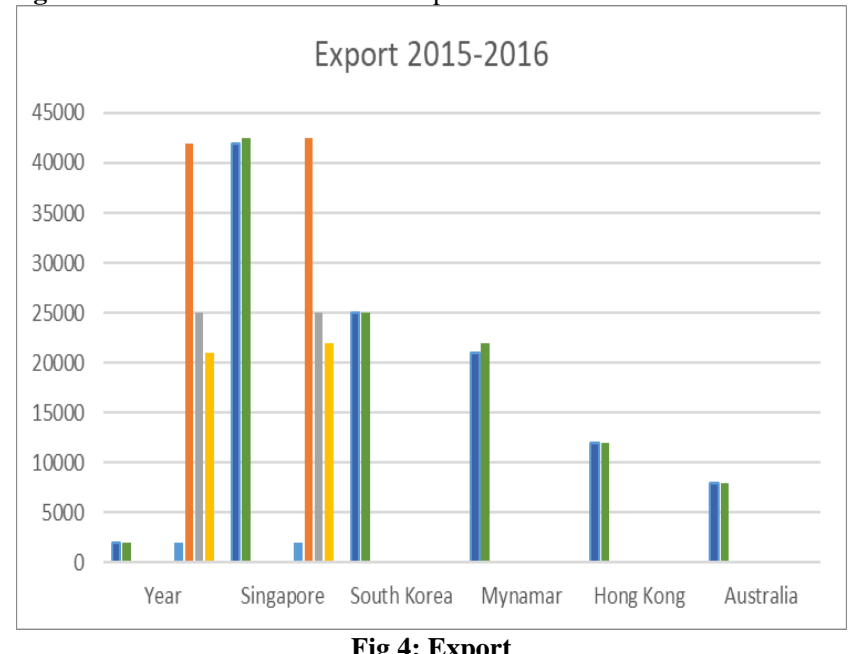

Source: "AA" Listed Corporation Annual Report 2015-2016

Whilst answering the call, whatever the respondents answered the items in the table were ticked. This is because it could be used to find out independent variables which contribute to the sustainable business growth and also to ascertain the causal link between the independent variables have the causal link with the mediator. During the telephone conversation with one of managerial post of the aforesaid corporation, independent variables such as fiduciary accountability, market orientation, innovation and growth were discussed. Insofar fiduciary accountability is concerned, care was taken not to intrude areas covered under the Data Protection Act, question on policies, serving best interest of the corporation, meeting the managers and encouraging innovative ideas among the employees were discussed. However, the product is more of monopoly as there is no competitor in Malaysia and it one of the main commodities for the consumers and manufacturers of foods and refreshments.

\section{2) SME (BB Private Limited)}

The aforesaid company commenced after the second world war and now it manufactures sweet for sore throat, slowly diversified in producing health drinks and packaging products. The company profile is headed by two directors, executive directors and comprising of 800 employees with the combination of skilled and unskilled workers. The annual turnover of RM 70 million per year and exporting products globally. As part of its growth, the products are branded and the company too has a trademark in this country. In order to promote the products, the company sponsor drinks for the sporting events throughout Malaysia.

Machines were purchased to increase the production existing machines are incrementally innovated.

\section{3) SME (CC Private Limited)}

It produces species of India origin to supply the locally and internationally. The aforesaid company was established in 1977 as sole proprietor which eventually transformed to medium sized enterprise incorporated as private limited with the object of producing organic species, curry powders and different types. Consequently, the corporate is headed by three directors, executive managers, engineers and workforce totalling over 500 .

The strategy of the corporation is to increase the sale. In order to increase the sale, the company has exported globally with branded and trademark. To ensure the quality control, the products are sent for laboratory testing to ensure it does not cause adverse health affect after consumption. Capturing the heart of the local, celebrated chief carry out one month programme of how to prepare various food.

Since the products are exported globally, technological change on production is undertaken and $\mathrm{R} \& \mathrm{D}$ is done internally to meet the secrecy of the species combination.

4) SMES (DD Private Limited)

The aforesaid corporation was formed by a group of local chefs to manufacture sausage locally. The capital was injected by them in which the company was incorporated in 1988. With some investment of machines, sausage is manufactured which is supplied in bulk in hotels, and packed with branded label throughout Malaysia. To date the total number of employees are fifty with management office located at the manufacturing site. The local market is more than enough to make profit. 


\section{SMES}

\section{RESULTS AND FINDINGS}

\section{A. AA Berhad}

The interview with one of the executive managers was cordial. During the interview the manager concerned answer the relevant areas such as fiduciary accountability. Also, BOD of directors have frequent meeting to devise plan and strategize the corporation growth and making sure profit is made. Policies from the subsidiary are revised by the executive with the consultation of BOD. Insofar innovation is concerned, manufacturing which is a subsidiary of the holding purchased new machines and some old machines were incrementally innovated. Since it is not longitudinal case study, it is rather difficult to comment about new machines purchased. The independent variable market orientation has the impact on sustainable business growth. Although the mass media carry the seriousness of over consumption the product, the market is not affected as the manufacturer is the monopoly. When question was asked about advertisement, the corporation does not spend aggressively on advertisement to lure customers. The product is used daily by each household, product is supplied regularly to soft drink manufacturers and other related food products manufacturers throughout Malaysia. At the international stage, the aforesaid company has captured Middle East countries, Singapore, Korea and other countries. The products are delivered in bulks which does not require branding of the product but the trademark carries the company's reputation. Fiduciary accountability of BOD contributes innovation incrementally. It is the corporate culture of the aforesaid corporation. The second hypothesis goes well as the incremental innovation increases the production over the years by not cutting the overtime of the employees. This is depicted in Figure 4 as the export to foreign countries did not drop.Manager concerned said that more countries have shown interest to purchase the product. Directors not only consider the welfare of the workers but also the business growth is sustained over the years. H4 where advertisement on social media is transmitted to lure customers is not necessary for this corporation. The theoretical framework of this study of which the independent variable of fiduciary accountability contributes to sustainable business growth and there is a causal link with independent variable with dependent variable. With the increase of production because of the increase of sale internationally, market orientation has the direct link to sustainable business growth and also moot innovation either incrementally or radically. During the interview session, one of the engineers remarked clarified that the BOD is reluctant to switch to full automation or not keen to replace the workforce with artificial intelligence. This is because the BOD wants to create more jobs as well as to overcome any alienation among their employees. It is company policy to adhere to environment sustainability as the processing of raw material does not pollute the environment.

\section{B. BB Private Limited SMEs}

The company speaks for its legacy. It is started off as the family business which has now transformed in the sense that are several subsidiary companies in and out of Malaysia. The holding company has refined corporate structure in which the Board of Directors is composed of family linkage. It was not a lengthy interview but managed to harness important information about the business. The fiduciary accountable of BOD is well-pronounced in this corporation. Most of crucial decision is decided by the BOD giving importance to the company growth. In one of subsidiary produces fruit juices and pack it for local and foreign market. For this particular product the marketing unit is given the task to boast the sale by having sale representatives in major supermarkets, posting on social media and reaching the masses by sponsoring continuous drinks for the participants and visitors during the supporting events. Products produced by the aforesaid corporation has a large share of Muslim market not only in Malaysia but also in Muslim nations globally. According to the marketing manager, promotion is done through major television channels, billboard and more importantly the trademark is our asset of the company sustainable business growth. Directors contribute to innovation not necessarily on technological aspects but on innovating quality products to fulfill the needs of the customers. This corresponds well to the hypothesis 1 and independent variable of fiduciary accountability of directors has the causal link with the innovation and sustainable business growth. For the sustainable business growth is more noted in the increase of sale and profit over the years. Insofar incremental innovation is concerned, the manager said that employees' innovative ideas are accepted with reward and such innovative ideas are put into effect incrementally.

This blends well with the hypothesis 2 as innovating incrementally increases the production and also improves the products. As for the hypothesis 4 whether advertisement on social media increases the sales is not necessarily correct as the manager said the products in the market are saleable because of the genuine and reliability of the products which captured the mind of the customers. Manager cautioned that there are other competitors in the market which requires our company to give more prominence in adverting the products on social media in near future to increase the sale. Theoretical framework of which market orientation contributes to sustainable business growth because of increase in exports. Likewise, fiduciary accountability of directors has causal link with innovation which stimulate the sustainable business growth. Market orientation influences innovation incrementally contributes the increase of production and sale all of which gives the sustainable business growth.

\section{DD Private Limited SMEs}

The meeting was not smooth flowing when sharing the company business information but relevant information was able to be extracted. Innovating of the products, packing, label and promoting the products through food preparations in the local media captured the new customers of all races. The products have made a breakthrough in the foreign markets and give a good competition of India counterparts. 
Based on the conversation which lasted for a week sporadically, replacing new machines or any technological change in production after the recommendation by an engineer would be finally decided by the directors. Existing machines are radically innovated by contracting experts from India. Coming to the $\mathrm{HI}, \mathrm{H} 2, \mathrm{H} 3$ and $\mathrm{H} 4$ are tested positively based on the interview. Independent variables namely fiduciary accountability and market orientation have the positive impact on innovation which in turn ensures the sustainable business growth. The direct link of both independent variables have the likewise effect.The sustainable business growth is seen at the angle of increase of sales and export.

\section{DD Private Limited SMEs}

The local sale is sufficient for the business sustainable growth. Not much fund is allocated for an advertisement and no products are posted on the social media. New machines were not purchased but hygienic care of production is the priority. Fiduciary accountability of directors contributes to the business growth but no innovation is carried to date. Since the product does not need advertisement, marketing is done directly by the directors because of good social networking. Independent variable of fiduciary accountability and market orientation contribute to sustainable business growth.

\section{E. Research Question}

In reality corporations studied both a listed and SMEs there is, of course, a causal link between the fiduciary accountability in contributing to sustainable business growth. At a glance, this may not blend well in medium sized enterprise but having studied the modus operandi of directors in the listed corporations are wider as they are watched by investors and regulated body monitoring their fiduciary duties. In contrast with the SMEs there is no regulative body to monitor their functions but the legislated corporate law has the necessary provision to check their accountability of their fiduciary function. In small sized enterprise, noted that there are two directors running their business and they make sure that they remain accountable in fiduciary sense to their company and this is only reflected in sustainable business growth. Suffice to say that these corporations give priority to promote their products not only to the local markets but also globally. For the products to become saleable, products, marketing label, quality and processing are innovated. As part of the fiduciary function directors do not simply approve on investing new machines because expenditure would drastically reduce their profit margin. In answering last question, the BOD of a listed corporation is accountable to their fiduciary action towards the company in general meeting. As long as the company harness good return, directors have performed their fiduciary function well and they would account of their success to the company. In comparison with SMEs, the same applies to fiduciary functions of directors and they would account their success to their shareholders.

\section{CONCLUSION}

The comparison between a list corporation and selected SMEs in regard to fiduciary accountability have causal link to sustainable business growth. Since the study was confined to food industry, directors' interest on the company is confined in seeking best interest and ensuring their sustainable business growth. Fiduciary accountability of BOD is well spelt in the company's constitution and Companies Act 2016. As a listed corporation directors have responsibilities to the company by making sure that any single steps taken is fruitful. Presuming erroneous business judgment such as overspending on innovation, the burden lies onto them to show that the decision is not made on male-fide and best interests of the corporation. AA listed corporation has a good earnings over the years and dividends are declared to the shareholders. Directors of SMEs in comparison play pivotal fiduciary role in ensuring the corporations are directed correctly with an assurance of sustainable business growth. Insofar practical purposes, it is appropriate for any corporations to have effective and practical policies such as cost and financing. Company should not place too much burden on fiduciary functions of directors and make them accountable for whatever outcome. Presuming innovation takes away the profit, it is desirable for the company to have a proper fiscal policy of which identifying problems by solving it with less problematic way. Currently, the global economy is slowing down and there are possibilities of corporations to encounter financial issues as local banks are no longer generous to approve and thus putting corporation to become venerable. While restructuring takes place in the business sector, policies have to be wisely devised in the sense that adequate alternative fund or liquidity should be made available to the prospective corporations. To overcome skyrocketing cost in Malaysia, there is in need of idealistic policy to restore corporate productivity and growth in near future. Policies which is currently needed is to restructure the framework for the purpose of alternative funding for the corporations. These corporations would not be overburden and repay without fearing bankers petitioning to the court to liquidate the company on the basis of inability to pay. Moreover, another policy which is needed is to correct the imbalance market so that new companies of small sized or medium would be not wiped out. In order to correct the imbalance, proper policy has to be designed institutionally, revising tax policy and other overarching policies have to be reviewed.

\section{ACKNOWLEDGEMENT}

This research work is funded by Universiti Sains Malaysia

\section{REFERENCES}

1. Amirav, D., \& Higginbottom, G. (2014). New emerging technologies in qualitative research. The Qualitative Report, 19(26)

2. Anneke, Z., Natalie, H., \& Ramón Gil-García, J. (2014). Special Issue on Innovation through Open Data - A Review of the State-of-the-art and an emerging research agenda: Guest editors' introduction. Journal of Theoretical and Applied Electronic Commerce Research, 9(2). doi: http://dx.doi.org/10.4067/S0718-18762014000200001 


\section{SMES}

3. Baker, William, E., Sinkula, \& James, M. (2002). Market orientation, learning orientation and product innovation: delving into the organization's Black Box. Journal of Market Focused Management,

4. Bee Chan, Koh, P., \& Ling., P. W. (2006). Malaysian Company Law (Second ed.). Malaysia: Swee \& Maxwell Asia.

5. Cohe, J., Malin, J., \& Sahpurwala, Z. (2013). Compare to US practice, evidence based- review in Europe appearto lead to lower prices for some drugs. Health Affairs, 32(4), 762--770.

6. Curran., J. (1999). The role of the small firm in the UK economy: Hot sterotypes and cool assessments. England.

7. Damanpour, Fariborz, Gopalakrishnan, \& Shanth. (2001). The dynamics of the adoption of product and process innovations in organizations. Journal of Management Studies, 38(1), 45-65.

8. Drucker, P. (1986). Innovation and entreppreneurship. New York,NY HapperColins.

9. e-Statistik. (2018). Statistic Malaysia. Statistic of Malaysia. doi: https://newss.statistics.gov.my/newss-portalx/ep/epDownloadContentSe arch.seam?cid=163087

10. Edelman, \& Suchman. (1997). The legal environments of organizations. Annual Reviewo of Sociology, 23, 479-515.

11. Flannigan, R. (2014). Shareholder fiduciiairy accountability. Journal of Business Law. doi: http://dx.doi.org/10.2319/ssrn.2147519

12. Freeman, C. (1994). Innovation and Growth. In: Handbook of Industrial Innovation (Mark Dodgson and Roy Rothwell ed.). UK: Aldershot, UK: Edward Elgar Publishing Limited.

13. Garcia, Rosanna, Calantone, \& Roger. (2002). A Critical Look at Technological Innovation Typology and Innovativeness Terminology: A Literature Review. Journal of Product Innovation Management, 19(2), 110-132.

14. Goa, M., \& Cui, B. (2016). Literature review on product distinctiveness evalaution and consumer choice on need for uniqueness. American Journal of Industrial and Business Management, 6, 840-845. doi: http://www; 10.4236/ajibm.2016.67079

15. Grudzewski, W., Hejduk, I., Sankowska, A., \& Wańtuchowicz, M. (2010). Sustainability $w$ biznesie, czyli przedsiębiorstwo przyszłości enterprise of the future - change management concepts. Warszawa, Poland: Poltext.

16. Han, Jin K., Kim, Namwoon, Srivastava, \& K., R. (1988). Market orientation and organizational performance: Is innovation a missing Link? Journal of Marketing, 62(4), 30-45.

17. Harding, M. (2013). Trust and Fiduciary Law. QJLS, 33, 85.

18. Harun, H., Said, Subramaniam, K., \& Ismail, 1. (2013). Factors influncing small medium enterprises in obtaining loan. International Journal of Business and Social Science, 4(15).

19. Hii, J., \& Neely, A. (2000). Innovative capacityoffirms: onwhy some firms are more innovative than others. Paper presented at the 7 th International Annual EurOMA Conference, Ghent.

20. Hironaka, C., Ashhari., M., \& Zairyawati. (2017). A comparative study of SMES in Japan and Singapore. 2, 359-374.

21. Hofer, C., \& Charan, R. (1984). The transaction to professional 9(11), 1-11.

22. Hollenstein, H. (1996). A Composite Indicator of a Firm's Innovativeness. An Empirical Analysis Based on Survey Data for Swiss Manufacturing, . Research Policy, 25, 633-645.

23. Holt, A. (2010). Using the telephone for narrative interviewing: a research note. Qualitative Research, 10(1), 113-122. doi: http://www.0.1177/1468794109348686

24. Jacob, B., \& Peters, L. S. (2015). The performance-improving benefits of a radical innovation initiative. International Journal of Productivity and

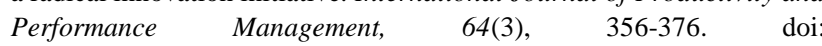
https://doi.org/10.1108/IJPPM-10-2014-0153

25. Jaworski, B., \& Kohli. (1993). Market orientation: antecedents and consequences. Journal of Marketing, 57, 53-70.

26. Joseph Warburton, A. (2011). Do fiducairy duties mater? Corporate governance. The internatinal journal of business in society, 11(5), 541-548. doi: https://doi.org/10.1108/1472070111176957

27. Keay, A. (2017). Stewardshi theory: is board accountability necessary? International Journal of Law and Management, 59(6), 1292-1314. doi: https://doi.org/10.1108/IJMA-11-2016-0118 5(5), 5-23. zmiany paradygmatói koncepcji zarzadzania [Sustainability in business, management: Mission impossible? American Journal of Small Business,

28. Kogut, B., \& Zander, U. (1992). Knowledge of the firm, combinative capabilities, and the replication of technology Organization Science, 3(2), 383-397.

29. Kolter, P. (2017). Philip Kotler, some of my adventures in marketing. Journal of Historical RESEARCH IN mARKETING, 9(2), 201-208. doi: https://doi.org/10.1108/JHRM-11-2016-0027

30. Kotler, P. (1993). Marketing management: A south Asian perspecitve. India: Peason.

31. Laine, K. (2012). Managing innovation for growth in high technology small firms in Aard Groen, Ray Oakey, Peter Van Der Sijde, Gary Cook (ed) (Vol. 2): Emerald Group Publishing Limited.

32. Lavakras, P. (1987). Telephone survey method, sampling and suprevision. Carlifornia: Sage.

33. Leifer, R., McDermott, M., 0'Connor, C., Peters, S., Rice, M., \& Veryzer, W. (2000). Radical innovation: How mature compainies can outsmart upstarts. Cambridge, MA: Havard Business School Press.

34. Ljiljana Božic, \& Ozretic-Došen., Đ. (2015). Enabling innovation and creativity in market-oriented firms. Baltic Journal of Management, 10(2), 144-165. doi: https://doi.org/10.1108/BJM-11-2013-0170

35. Major, L. (2009). Paki v Attorney General. Gladstone, 16(140).

36. Mathers, N., Fox, N., \& Hunn, A. (2002). Using Interviews in a Research Project. Trent, US: Trent Focus Group

37. Maxwell, \& Ernest, I. (2009). Managing sustianable innovation. New York: Springer.

38. Minna, S. (2016). Performance measurment apporoaoooch for innovation capability. International of Productivity and Performance Management, 65(2), 162-176. doi: https://doi.org/10.1108/1jppm-08-2014-0213

39. Mitsuru Kodama, \& Shibata, T. (2015). Strategy transformation through innovation capability- a case study of Fanuc. $R \& D$ Management, 44(1), 75-103. doi: https://doi/10.111.radm12041

40. Mukherjee, A., \& Hoyer, W. D. (2001). The effects of novel attributes on product evaluation. Journal of Consumer Research, 26, 462-472. doi: http://dx.doi.org/10.1207/1532766026038237

41. Narver, J. C., \& Slater, C. F. (1990). The effect of a market orientation on business profitability,. Journal of Marketing 54, 20-35.

42. Narver., Slater, F. S., \& Tietje, c. B. (1998). Creating a market orientaiton. Journal of Market Focused Management, 2(3), 241-245. doi: https://www.doi.org/10.1023A:1009703717144

43. O'Connor, G. (2006). Open, radical innovation;toward an integrated model in large firms. New York: Oxford University Press.

44. Odoom, R., Dorson, T., \& Acheampong., G. (2017). Antecedents of social media usagne and performance benefits in small and medium sized enterpsies (SMES). Journal of Enterprise Information(30), 363-398. doi: http:dx.doi.org/10.11.08/jEIM-04-2016-0088

45. Oliver, C. (1991). Strateic responses to institutional processes. Academy Management Review, 16(1), 145-179. doi: 10.5465/amr.1991.4279002

46. Palmer, Roger, Brookes, \& Richard. (2002). Incremental Innovation: A case study analysis. Journal of Database Management, 10(1), 71-83.

47. Pappenheim, C. (2016). Incremental innovation effects on consumer perception. Sceince Journal of Business Management, 6(1), 10. doi: http://www.doi10.7237/sjbm272

48. Pilon, T. (1982). Capitalism and rights: An essay to right tunning the moral foundation of the society. Journal of Business Ethics, 29, 31.

49. Sandberg, B. (2008). .Managing and marketing radical innovations : Marketing new technology. London: Routledge.

50. Sany Sanuri, M., Rushami, Z. Y., \& Azanin, A. (2014). Key elements of market oreintation on Malaysian SMEs performance. International Journal of Business and Society, 15(1), 49-64.

51. Schillemans, T., \& Basuioc, M. (2015). Predicting public sector Accountability : From agency drift to forum drift. . Journal of Public Administration Research and Theory(25), 191.

52. Schlenker, B. R. (1980). Impressions management: The self-concept, social identity, and interpersonal relations Belmont, CA: Brooks-Cole.

53. Schumpeter, J. A. (2011). The theory of economic development: An inquiry into profits, capital, credit, interest and the business cycle. Cambridge, MA: Harvard Business School Press.

54. Shengyen, L., Ursula, R., \& KattnerCarelyn, C. (2017). A computational framework for material design. Integrating Materials and Manufacturing Innovation, 6(3), 229-248. doi:

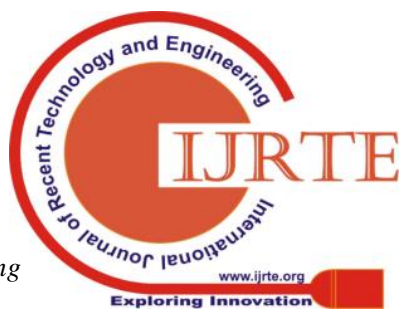


55. Simmonds, K. (1986). Marketing as innovation; the eight paradigm. Journal of Management Studies, 5(23).

56. SMEs Corporation, M. (2016). SME Annual Report 2016/2017: SME Corporation Malaysia.

57. Stenning, C., Philip. (2000). Power and accountability of private police. European Journal on Criminal Policy and Research, 8(3), 325-352. doi: https://doi.org/10.1023/A:1008729129953

58. Szczepanska-Woszcyna. (2014). SMEs managersa need for competence. Acta Technologies Dubnicae, 4(4), 1-16.

59. Szczepanska-Woszcyna. (2016). Sustainable business development through leadeship in SMEs. Econmics and Management, 8(3), 57-69. doi: https://www..doi:10.1515/emj-2016-0024

60. Tetlock. (1983). Accountability and the perseverance of first impressions Social Psychology Quarterly 285292.

61. Tetlock, Skitka, I., \& Boettger, R. (1989). Social and cognitive strategies for coping with accountability: Conformity, complexity, and bbolstering, . Journal of Personality and Social Psychology (October), 632-640.

62. Tetlock. (1985). Accountability: A social check on the fundamental attribution error. Social Psychology Quarterly (September), 227-236.

63. Tushman, Michael, L., O'Reilly, \& A., C. (1977). Winning through Innovation: A Practical Guide to Leading Organizational Change and Renewa. Boston: Harvard Business School Press. Utterbac.

64. Vogl, S. (2013). Telephone versus face-to-face interviews: mode effect on semi-structurediInterviews with children. Sociological Methodology, 16(1), 133-177. doi: http://www.0.1177/0081175012465967

65. Waters, D. (1986). Banks, fiduciary and unconscionable transactions. CanBar eview, 37, 48-56.

66. Weinrib, E. (1975). The fiduciary obligation. UTLJ, 1,5

67. Williamson. (1966). Mechanism of governance. Oxford: OUP.

68. World Bank. (2018). The World Bank in Malaysia. 